\title{
COPING STYLES AND PERSONALITY TRAITS AMONG DEPRESSED PATIENTS
}

\author{
Prof. Sanaa Habashi Abd Elmgeed, Dr.Amal Sobehy Mahmoud, \\ Dr. Abeer El Sayed Berma, Rehab Talal Ali Elfaoumy \\ Professor of Psychiatric Mental Health Nursing - Faculty of Nursing- \\ Alexandria university, Assist prof in Psychiatric Nursing and Mental Health- \\ Faculty of Nursing-Port Said University, Lecturer in Psychiatric Nursing and \\ Mental Health-Faculty of Nursing- Port Said University
}

\begin{abstract}
Background: The association between personality traits and coping styles suggest that individuals with maladaptive personalities are at a greater risk for experiencing psychological distress as they probably use a maladaptive coping style such as avoidant coping.So, study aimed to identify the relation between coping styles and personality traits among depressed patients. The study sample consisted of 150 patients in the psychiatric health hospital in Port Said City, Using descriptive comparative design. Data was collected through using three tools, The Ways of Coping Questionnaire, An Arabic Version of Beck Depression Inventory and The Big Five Personality. Results: The study showed that participants with depression and neuroticism as personality traits using escape avoidance as maladaptive coping style and distancing coping style has significant negative correlation with this neuroticism trait. Moreover, the results revealed that all types of personality traits and coping styles had significant relation with all levels of depression. Conclusion The current study suggests that personality traits and the coping styles the individual employ may influence his experience of depression. Furthermore, the association between personality traits and coping styles suggests that individuals with neuroticism as personalities traits are at a greater risk for experiencing depression as they are more likely to use a maladaptive coping style such as avoidant coping. Recommendation: educational programs for depressed patients which aim to educate them how to use new adaptive coping.
\end{abstract}

Keywords: coping; depression; personality traits. 


\section{INTRODUCTION}

Depression is the most causing disabilities worldwide. It affected all the areas of the person's life. Some personality traits and the way the individual cope may be factors that are important in the development of depression. Coping refers to the thoughts and actions that the individual use to deal with a threatening situation. In general, people strive to retain, protect, and build coping resources as they experience threats that result in perceived potential loss of resources ((Larry, 2003). The relationship of personality traits and coping processes has been considered in many studies (Admiraal et al., 2000; Moos and Holahan, 2003; Van Berkel, 2009). Personality is an abstract intangible concept elicited by a combination of behaviors, thoughts, motivations, emotions, etc. Each person has a unique personality. Personality trait influences what the individual think, beliefs, values and expectations. Personality traits play an important role in the method with which an individual copes with various problems (Caspi and Shiner 2006). As the study of personality and coping styles is a relatively new area of research, no studies as yet have examined whether having both a maladaptive personality and maladaptive coping style predicts greater psychological distress compared to either predictor alone. This is an important area to study, especially as some researches suggests that personality and coping styles are associated with one another (Karimzade and Besharat, 2011).So this study was done to explore the relationship between personality traits, coping styles and depression .

\section{AIM OF THE STUDY:}

This study aimed to explore the relation between coping styles and personality traits among depressed patients.

\section{Research Questions:}

1. What are the coping styles used by depressed patients?

2. What are the types of personality traits among depressed patients?

3. Is there a relation between coping styles and personality traits among depressed patients?

\section{SUBJECTS AND METHOD:}

\section{Study Design:}

Descriptive correlational design was used in this study. 


\section{Study Setting:}

This study was carried out in out patients' clinic of Port-Said Psychiatric health hospital, Port-Said, Egypt. The hospital is affiliated to the Ministry of Health. The Psychiatric health hospital capacity is 150 beds; the hospital serves three governorates namely Port Said, El Ismailia and El Suez.

\section{Study Population:}

The sample size was determined by the Epi info 7 programs using the following parameters:

1. Population size $=1200$ patients (The number of patients who repeatedly visit the outpatient clinic over a period of three months from the outpatient records at PortSaid Psychiatric health hospital

2. Expected frequency $=50 \%$

3-Acceptable error $=10 \%$

4-Confidence coefficient $=99 \%$

The program revealed a minimum sample size to be 146 patients with depression. Thus it was decided in the present study to recruit a convenient sample of 150 having depression as it was recorded in the hospital statistical records for follow-up and treatment.

\section{Exclusion criteria:}

Patient with psychiatric co-morbidity.

\section{Tools of Data Collection:}

Three tools were used for data collection.

\section{TOOL (1): The Ways of Coping Questionnaire (WOC)}

This tool was developed by Folkman and Lazarus (1986) to assess thoughts and actions that individuals use to cope with stressful encounters of everyday living. It contains 66 items rated on a 4 likert -type scale that ranges from 0 (does not apply or not used) to 3 (used a great deal). The ways of coping questionnaire (WOC) contain 8 coping-scales which represent the following: Confrontive coping, distancing, selfcontrolling, seeking social support, accepting responsibility, escape-avoidance, planful problem solving, and positive reappraisal.

\section{TOOL (2): An Arabic Version of Beck Depression Inventory}

The Beck Depression Inventory (BDI) is a scale developed by Beck (1967) and 
translated by Ghareeb (2000). It is used to measure the intensity, severity and depth of depression in patients with psychiatric diagnosis. It comprises 21 items, each one consists of four alternative statements that represent gradations of a given symptom rated in severity from $0-3$. Items 1 to13 assess symptoms that are psychological in nature as assess mood, pessimism, sense of failure, self-dissatisfaction, guilt, punishment, self-dislike, self-accusation, suicidal ideas, crying, irritability, social withdrawal, body image, work difficulties while items 14 to 21 assess more physical symptoms as insomnia, fatigue, appetite, weight loss, bodily preoccupation and loss of libido. Total scores range from 0 to 63 , with higher scores reflecting severe depression as follows:

1. $0-9 \rightarrow$ Represent minimum depressive symptoms.

2. $10-16 \rightarrow$ Mild depression.

3. $17-29 \rightarrow$ Moderate depression

4. 30 or more $\rightarrow$ severe depression

\section{TOOL (3): An Arabic Version of the Big Five Personality Inventory}

This tool was developed by John (2000) and translated by Elfaoumy (2011). It was used to assess the big five dimensions of personality traits (Openness, Extraversion, Agreeableness, Neuroticism and Conscientiousness). The scale consists of 44 questions with five - point Likert scale. Extraversion questions are 1,6R, 11, 16, 21R, 26, 31R and 36. Agreeableness questions are 2R, 7, 12R, 17, 22, 27R, 32, 37R and 42. Conscientiousness questions are 3, 8R, 13, 18R, 28, 23R, 33, 38 and 43R. Neuroticism questions are 4, 9R, 14, 19, 24R, 29, 34R and 39. Openness questions are $5,10,15,20,25,30,35 R, 40,41 R$ and 44 . " $R$ " denotes reversed scored items.

Participants' answers using a five-point Likert scale where 5 indicating strongly agree to 1 indicating strongly disagree. Personality trait will represent the highest score of any one of the five dimensions.

In addition, a socio-demographic was added. It included patient's characteristics as: age, sex, marital status and level of education.

\section{Tools Validation:}

The tools were ascertained by a jury composed of five experts in nursing and medical psychiatric field. Their opinions were elicited regarding the tool layout, parts and items. 


\section{Reliability of the Tool:}

Chronbach alpha coefficient was calculated to assess the reliability of (Tool 3 An Arabic Version of Big Five Personality Inventory), through their internal consistency (Average reliability of 44 statements $r=0.73$ ). This phase was carried out in a period of one month.

\section{Pilot Study:}

A pilot study was carried out after the development of the tools and before starting the data collection. It included 30 patients and was conducted from the 2014/1/1 to the 2014/2/4. The pilot study was carried out to test the clarity, applicability and feasibility of the study tools, to estimate the needed time to complete the tools and to find out any problems that might interfere with the data collection. After obtaining the results of the pilot study, the necessary modifications were done. The ambiguous items were modified according to the patients' responses. The final form was then developed.

\section{Field Work:}

Before starting any step in the study, an official permission to conduct the study was obtained from the Director of the Mental Health Hospital in Port Said city.

1. Data collection was done in Port-Said Psychiatric health hospital, during the period from the first of January 2014 to the end of June 2014.

2. An oral consent was taken from each patient in the study after explaining the purpose and the importance of the study, a complete confidentiality of the obtained information and privacy of the patients were ensured.

3. Patient's demographic and clinical data were collected through interviewing and reviewing the patient's medical charts using the demographic and Clinical data structured interview schedule.

4. The number of patient interviewed was 3-4 / day for 3 days per week each interview lasted about $20-30$ minutes, depending on the response of interviewee. 


\section{Ethical Considerations:}

Before starting any step in the study, an official permission to conduct the study was obtained from the Director of the Mental Health Hospital in Port Said city. Additionally, an oral consent was taken from each person in the study, after explaining the purpose and the importance of the research to each one of them, they were informed about their right to not participate in the study and that their answers will not be taken against them, it will be used just for the purpose of the study.

\section{Statistical analysis:}

The raw data were coded and entered into SPSS system files (SPSS package version 18). Analysis and interpretation of data were conducted.

The following statistical measures were used:

- Descriptive statistics including frequency, distribution, mean, and standard deviation were used to describe different characteristics.

- Linear correlation, using Spearman Rho correlation coefficient, was conducted to show correlation between personality traits, level of depression, coping styles among depressed patients.

- The significance of the results was at the $5 \%$ level of significant

\section{RESULT:-}

Table (1): shows the distribution of depressed patients according to their socio demographic characteristics. The respondents of the study were 150 depressed patients with mean age $39.2 \pm 11.7,31.3 \%$ of them were age between $40-50$ years old. As regard patient's sex, more than half of them were males $(56.0 \%)$. It was noted that more than half of depressed patients $52.6 \%$ were married and most of them were single. In relation to educational level, one third of the studied depressed patients $(33.3 \%)$ had university or postgraduate education.

Figure (1) shows the distribution of patient with depression according to their level of depression, one third of depressed patients (33.3\%) had severe level of depression, $40.7 \%$ of them had moderate level of depression; where $17.3 \%$ had minimal level of depression and only $8.7 \%$ had mild level of depression and the mean level of depression was $23.8 \pm 11.1$ among depressed patients. 
Figure (2): illustrate that neuroticism as personality trait was found to have the highest percent $(81.3 \%)$ among depressed patients. While, there was no extraversion personality trait was found among them.

Figure (3): It was found that escape avoidance coping style get highest mean score of using among depressed patients $11.5 \pm 6.8$, while, accepting responsibility coping style was the lowest one.

Table (2): describes the correlation between personality traits \& coping styles among depressed patients. Pearson correlation coefficient revealed that, confront coping style has significant negative correlation with all dimensions of personality traits except agreeableness personality trait $(\mathrm{p}=0.0001, \mathrm{p}=0.012, \mathrm{p}=0.003, \mathrm{p}=$ 0.0001 respectively) . Regarding distancing coping style, it was noted that distancing coping style has significant negative correlation with neuroticism, conscientiousness and openness personality traits $(\mathrm{p}=0.001, \mathrm{p}=0.022, \mathrm{p}=0.0001$ respectively).

Concerning self- controlling coping style, it was noted that significant negative correlation with self- controlling coping style, neuroticism and openness personality traits at $\mathrm{p}=0.0001$ While seeking social support coping style has significant positive correlation with extraversion personality trait at $\mathrm{p}=0.001$ and significant negative correlation with openness personality trait at $\mathrm{p}=0.003$. Concerning accepting responsibility, planful problem solving and positive reappraisal coping styles significant negative correlation was found between these coping styles and all dimensions of personality traits. Furthermore, significant positive correlation was noted between escape- avoidance coping style and neuroticism personality trait at $\mathrm{p}=0.0001$ (prominent neuroticism personality trait greater the use of escape avoidance coping), while significant negative correlation was found between escape avoidance coping style and openness personality trait at $\mathrm{p}=0.024$. 
Table (1): Socio demographic characteristics of the depressed patients.

\begin{tabular}{|c|c|c|}
\hline $\begin{array}{c}\text { Socio- demographic } \\
\text { Characteristics }\end{array}$ & $\begin{array}{l}\text { No. } \\
150\end{array}$ & $\%$ \\
\hline $\begin{array}{l}\underline{\text { Sex }} \\
\text { Male } \\
\text { Female }\end{array}$ & $\begin{array}{l}84 \\
66\end{array}$ & $\begin{array}{l}56.0 \\
44.0\end{array}$ \\
\hline $\begin{array}{l}\text { Age } \\
20- \\
30- \\
40- \\
50- \\
60 \text { or more }\end{array}$ & $\begin{array}{l}34 \\
43 \\
47 \\
14 \\
12\end{array}$ & $\begin{array}{l}22.7 \\
28.7 \\
31.3 \\
9.3 \\
8.0\end{array}$ \\
\hline $\begin{array}{l}\text { Range } \\
\text { Mean } \pm \text { SD }\end{array}$ & & \\
\hline $\begin{array}{l}\text { Marital status } \\
\text { Single } \\
\text { Married } \\
\text { Divorced } \\
\text { Widow }\end{array}$ & $\begin{array}{c}57 \\
79 \\
4 \\
10\end{array}$ & $\begin{array}{c}38.0 \\
52.6 \\
2.7 \\
6.7\end{array}$ \\
\hline $\begin{array}{l}\text { Educational level } \\
\text { Illiterate/Read and write } \\
\text { Basic Education } \\
\text { (primary/preparatory) } \\
\text { Secondary Education } \\
\text { University/Postgraduate }\end{array}$ & $\begin{array}{l}15 \\
43 \\
42 \\
50\end{array}$ & $\begin{array}{l}10.0 \\
28.7 \\
28.0 \\
33.3\end{array}$ \\
\hline
\end{tabular}




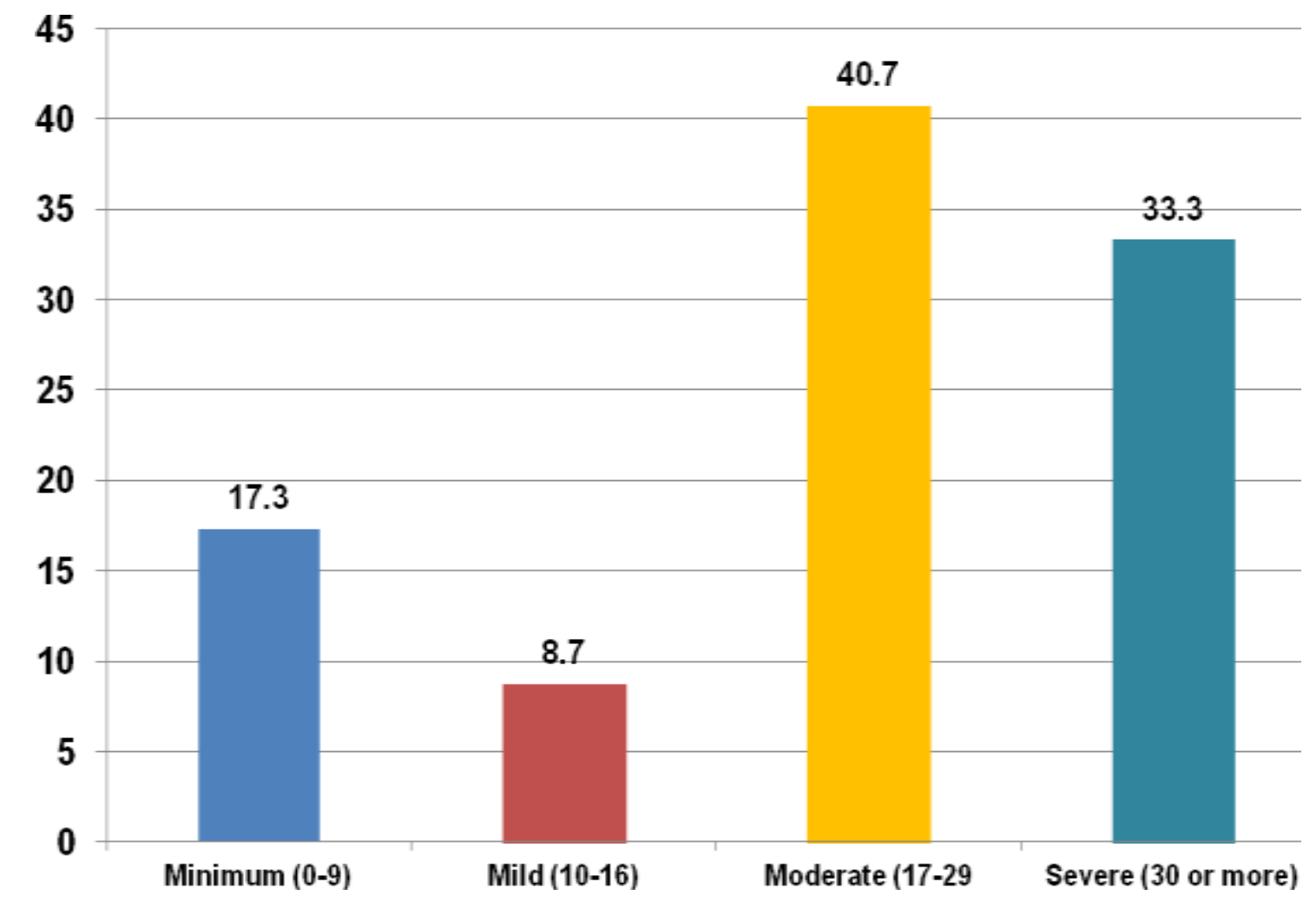

Figure (1): Distribution of patients with depression according to level of depression.

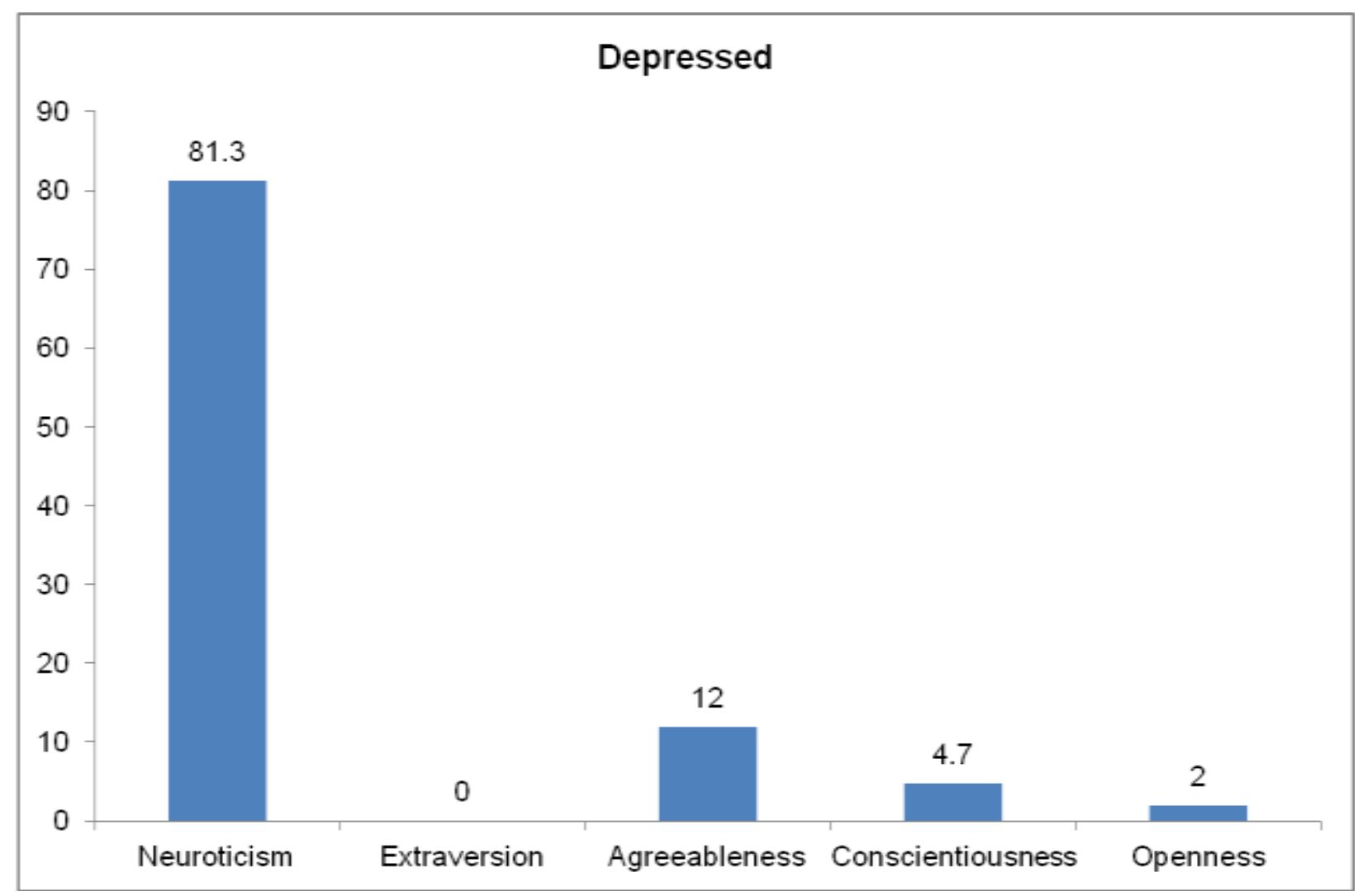

Figure (2): Personality traits of the depressed patients. 


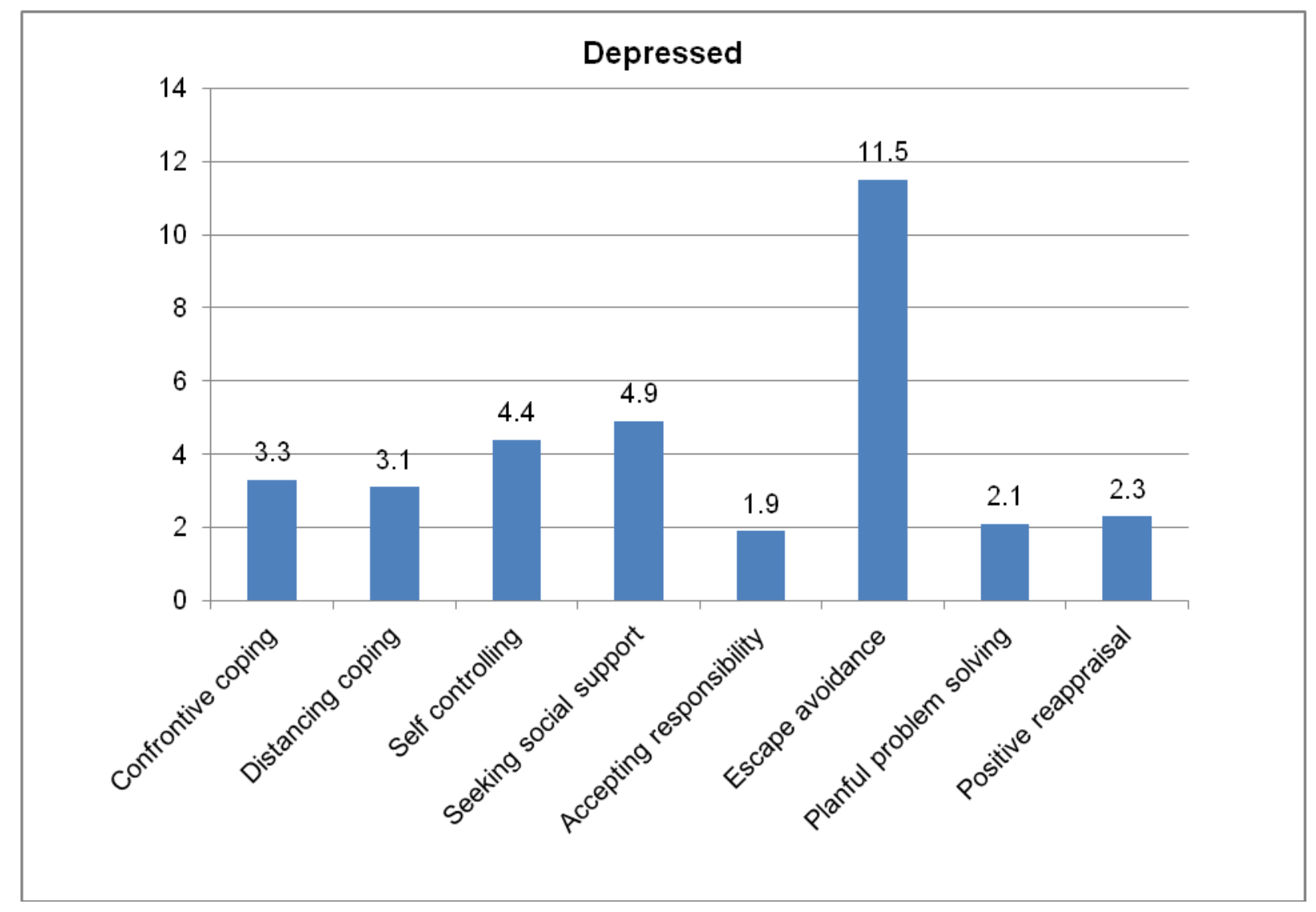

Figure (3): The mean of using coping styles in the depressed patients. 
Table (2): Correlation between personality traits \& coping styles among depressed patients

\begin{tabular}{|c|c|c|c|c|c|c|c|c|c|c|}
\hline \multirow{3}{*}{ Coping style } & \multicolumn{10}{|c|}{ Personality traits for patients with depression $(n=150)$} \\
\hline & \multicolumn{2}{|c|}{$\begin{array}{l}\text { Neuroticis } \\
\text { m }\end{array}$} & \multicolumn{2}{|c|}{$\begin{array}{l}\text { Extraversi } \\
\text { on }\end{array}$} & \multicolumn{2}{|c|}{$\begin{array}{l}\text { Agreeablene } \\
\text { ss }\end{array}$} & \multicolumn{2}{|c|}{$\begin{array}{c}\text { Conscientiou } \\
\text { sness }\end{array}$} & \multicolumn{2}{|c|}{ Openness } \\
\hline & $\mathbf{r}$ & $\mathbf{P}$ & $\mathbf{r}$ & $\mathbf{P}$ & $\mathbf{r}$ & $\mathbf{P}$ & $\mathbf{r}$ & $\mathbf{P}$ & $\mathbf{r}$ & $\mathbf{P}$ \\
\hline $\begin{array}{l}\text { Confrontive } \\
\text { coping }\end{array}$ & $\begin{array}{c}- \\
0.3 \\
68\end{array}$ & $\begin{array}{l}0.00 \\
01 *\end{array}$ & $\begin{array}{c}- \\
0.2 \\
04\end{array}$ & $\begin{array}{r}0.01 \\
2 *\end{array}$ & $\begin{array}{c}- \\
0.15 \\
3\end{array}$ & $\begin{array}{c}0.06 \\
1\end{array}$ & $\begin{array}{c}- \\
0.24 \\
4\end{array}$ & $\begin{array}{c}0.00 \\
3^{*}\end{array}$ & $\begin{array}{c}- \\
0.36 \\
3\end{array}$ & $\begin{array}{l}0.00 \\
01 *\end{array}$ \\
\hline Distancing coping & $\begin{array}{c}- \\
0.2 \\
6\end{array}$ & $\begin{array}{c}0.00 \\
1 *\end{array}$ & $\begin{array}{c}- \\
0.0 \\
85\end{array}$ & $\begin{array}{c}0.30 \\
3\end{array}$ & $\begin{array}{c}- \\
0.05 \\
5\end{array}$ & $\begin{array}{c}0.50 \\
5\end{array}$ & $\begin{array}{c}- \\
0.18 \\
6\end{array}$ & $\begin{array}{c}0.02 \\
2 *\end{array}$ & -0.5 & $\begin{array}{l}0.00 \\
01 *\end{array}$ \\
\hline Self controlling & $\begin{array}{c}- \\
0.3 \\
97\end{array}$ & $\begin{array}{l}0.00 \\
01 *\end{array}$ & $\begin{array}{l}0.0 \\
68\end{array}$ & $\begin{array}{c}0.40 \\
8\end{array}$ & $\begin{array}{c}0.13 \\
9\end{array}$ & 0.09 & $\begin{array}{c}0.00 \\
5\end{array}$ & $\begin{array}{c}0.95 \\
1\end{array}$ & $\begin{array}{c}- \\
0.29 \\
8\end{array}$ & $\begin{array}{l}0.00 \\
01 *\end{array}$ \\
\hline $\begin{array}{l}\text { Seeking social } \\
\text { support }\end{array}$ & $\begin{array}{l}0.0 \\
58\end{array}$ & $\begin{array}{c}0.47 \\
7\end{array}$ & $\begin{array}{l}0.2 \\
71\end{array}$ & $\begin{array}{r}0.00 \\
1 *\end{array}$ & $\begin{array}{c}0.15 \\
7\end{array}$ & $\begin{array}{c}0.05 \\
6\end{array}$ & 0.07 & $\begin{array}{c}0.39 \\
2\end{array}$ & $\begin{array}{c}- \\
0.24 \\
1\end{array}$ & $\begin{array}{l}0.00 \\
3 *\end{array}$ \\
\hline $\begin{array}{l}\text { Accepting } \\
\text { responsibility }\end{array}$ & $\begin{array}{c}- \\
0.3 \\
85\end{array}$ & $\begin{array}{l}0.00 \\
01 *\end{array}$ & $\begin{array}{c}- \\
0.3 \\
12\end{array}$ & $\begin{array}{l}0.00 \\
01 *\end{array}$ & $\begin{array}{c}- \\
0.19 \\
7\end{array}$ & $\begin{array}{c}0.01 \\
6^{*}\end{array}$ & $\begin{array}{c}- \\
0.43 \\
3\end{array}$ & $\begin{array}{l}0.00 \\
01 *\end{array}$ & $\begin{array}{c}- \\
0.48 \\
8\end{array}$ & $\begin{array}{l}0.00 \\
01 *\end{array}$ \\
\hline Escape avoidance & $\begin{array}{l}0.6 \\
13\end{array}$ & $\begin{array}{l}0.00 \\
01 *\end{array}$ & $\begin{array}{c}- \\
0.0 \\
6\end{array}$ & $\begin{array}{c}0.46 \\
6\end{array}$ & $\begin{array}{c}- \\
0.38 \\
5\end{array}$ & $\begin{array}{l}0.00 \\
01 *\end{array}$ & $\begin{array}{c}- \\
0.06 \\
8\end{array}$ & $\begin{array}{c}0.40 \\
7\end{array}$ & $\begin{array}{c}- \\
0.18 \\
4\end{array}$ & $\begin{array}{r}0.02 \\
4 *\end{array}$ \\
\hline $\begin{array}{l}\text { Planful problem } \\
\text { solving }\end{array}$ & $\begin{array}{c}- \\
0.3 \\
13\end{array}$ & $\begin{array}{l}0.00 \\
01 *\end{array}$ & $\begin{array}{c}- \\
0.2 \\
29\end{array}$ & $\begin{array}{r}0.00 \\
5 *\end{array}$ & $\begin{array}{c}- \\
0.22 \\
2\end{array}$ & $\begin{array}{c}0.00 \\
6^{*}\end{array}$ & $\begin{array}{c}- \\
0.31 \\
7\end{array}$ & $\begin{array}{l}0.00 \\
01 *\end{array}$ & $\begin{array}{c}- \\
0.44 \\
9\end{array}$ & $\begin{array}{l}0.00 \\
01 *\end{array}$ \\
\hline $\begin{array}{l}\text { Positive } \\
\text { reappraisal }\end{array}$ & $\begin{array}{c}- \\
0.2 \\
3\end{array}$ & $\begin{array}{c}0.00 \\
5 *\end{array}$ & $\begin{array}{c}- \\
0.2 \\
83\end{array}$ & $\begin{array}{l}0.00 \\
01 *\end{array}$ & $\begin{array}{c}- \\
0.29 \\
1\end{array}$ & $\begin{array}{l}0.00 \\
01 *\end{array}$ & $\begin{array}{c}- \\
0.24 \\
8\end{array}$ & $\begin{array}{c}0.00 \\
2 *\end{array}$ & -0.5 & $\begin{array}{l}0.00 \\
01 *\end{array}$ \\
\hline
\end{tabular}

r: Spearman Rho correlation coefficient $*$ significant at $P<0.05$ 


\section{DISCUSSION:}

Coping is a dynamic process that fluctuates over time in response to changing demands and appraisals of the situation. Coping is a stabilizing factor that helps maintain psychological adjustment during stressful periods; accordingly, coping efforts should be most helpful when there is a high level of stressors (Moos and Holahan, 2003).

A depressive state can occur in reaction to an acute stressor, multiple stressors, or no apparent cause, producing a brief disturbance in mood, cognitions and behavior. However, a mood disturbance may be classified as a disorder if it remains unresolved over time and is coupled with multiple depressive symptoms (Gomez and Francis, 2003; Grabowska-Grzyb et al., 2006). Many theories of depression propose a diathesis-stress model, in which a stressor interacts with an individual's biological or cognitive vulnerability to produce a depressive reaction (Alloy et al., 2000; Caspi et al., 2003).

The severity and temporal characteristics of the stressor(s), as well as the individual's biological and genetic makeup, use of coping skills, cognitive style, personality traits and degree of social support, may contribute to development of depression. Hence, the present study was carried out to identify the relation between coping styles and personality traits among depressed patients. With the hope of increasing nurses awareness about these coping styles and personality traits among depressed patients, to increase the effectiveness of depression treatment (Matheson and Anisman, 2003; Scher et al., 2005; Gladstone et al., 2007).

The results of the current study indicated that most of the studied depressed patients had a neuroticism personality trait. This finding may be due to neuroticism trait is a factor in the development of depressive disorders, these persons tend to be more anxious, pessimistic, stressed all the time all of these characteristics may lead the person to have depression at any time of their life. This result was in agreement with Griffith et al., (2010), they found that a neuroticisms was a necessary factor in mood and anxiety disorders .

The results of the present study indicated that there was no extraversion personality trait among the depressed patients. This result may be due to extraversion 
personality characterized by sociability and it is different from persons with depression. However, a study done by Lucas and Braid (2004) showed that extraverted person is more sensitive and acted more negatively to stress than introverted person. Consequently, they may prone to have depressive symptoms.

Concerning agreeableness, conscientiousness and openness personality traits less found with depressed patients. These findings may be due to the characteristics of these traits are not congruent with the characteristics of the depressed person. In the same line, some researchers proposed that neuroticism is negatively related to health and well being whereas extraversion, conscientiousness, agreeableness and openness are positively related to the same (Malouff et al., 2005; Steel et al., 2008; Kotov et al., 2010).

The results of this study revealed statistical negative significant correlations between neuroticism personality trait, confrontive, distancing, self controlling, accepting responsibility, planful problem solving and positive reappraisal coping styles. Moreover, positive significant relation correlations between neuroticism personality trait and escape avoidance coping style. This result may be due to the fact that personality may affect coping strategy selection directly, by constraining or facilitating use of specific strategies, or indirectly, by influencing the nature and severity of stressors experienced or the effectiveness of coping strategies and neurotic individuals prefer to escape from their problems, so they use escape avoidance coping style (Marnie, 2008).

The present study revealed statistical negative significant relation was found between confrontive, accepting responsibility, planful problem solving, positive reappraisal coping styles and extraversion personality trait. However, positive and significant relation was found between extraversion personality trait and seeking social support coping style, this finding may attributed to non of the depressed patients in the study subjects have this personality trait.

The results of current study noted that negative and significant relation was found between accepting responsibility, escape avoidance, planful problem solving, positive reappraisal coping styles and agreeableness personality trait. Furthermore, negative and significant relation was found between confrontive, distancing, accepting responsibility coping style, planful problem solving, positive reappraisal 
coping styles and conscientiousness personality trait. Moreover, it was noted negative and significant relation was found between openness personality trait and all coping styles. The rational of this result may be due to personality traits may influence the effectiveness of coping styles. It means the styles that are useful for some individuals may be less effective or even harmful for individuals that have different personality traits. This result supported by some researchers who assume that coping styles can directly be derived from personality traits; indeed, coping is personality in action (Malone, 2010; Ebstrup et al., 2011).

\section{CONCLUSION AND RECOMMENDATIONS:}

Based on the findings of the current study, it can be concluded that a significant correlation between personality traits and coping style among depressed patients. The results show that depression is associated with traits such as neuroticism/negative emotionality . Moreover, escape avoidance coping style more used with depressed patients. Finally, No statistically significant differences were found for depressed patients according to their socio demographic characteristics.

\section{Based on the present study findings, the following recommendations are suggested:}

- Continuing educational program for nurses in the form of workshops, conferences and review update in coping styles, personality, depression and encourage nurses to attend the different training programs.

- Personality trait dimensions and different coping styles should be included in the patient's records to determine the patients' trait that help nurses to provide optimal nursing care for patients and cope effectively.

- Implementation of Psycho-educational programs for depressed patients which aim to:

-Educate patients and their family members about how to deal with life stressors through using adaptive coping styles to prevent and decrease the occurrence of depression.

- Increase patient's awareness about their personality traits and its causes, are recommended.

- Future research is needed to assess the effectiveness of educational programs for depressed patients about coping styles. 


\section{REFERENCES:}

Admiraal F., Korthagen A., Wubbels T.(2000). Effects of student teachers' coping behavior. British Journal of Educational Psychology, 70 (1): 33-52.

Alloy B., Abramson Y., Hogan E., Whitehouse G., Rose T., Robinson S., et al. (2000). The Temple-Wisconsin Cognitive Vulnerability to Depression (CVD) Project: Lifetime history of Axis I psychopathology in individuals at high and low cognitive risk for depression. Journal of Abnormal Psychology, 109: 403-418.

Beck T. (1967). Depression: causes and treatment. USA: University of Pennsylvaniapress.Availableat:http://books.google.com/books?id=6rigtdo0u2UC\&p $\underline{\text { rintsec}}=$ frontcover $\& d q=$ depression $\&$ hl=ar\#PPA174, M1.Retrived on:May.2016.

Caspi A., Sugden D., Moffitt E., Taylor A., Craig W. et al. (2003). Influence of life stress on depression: moderation by a polymorphism in the 5-HTT gene. Science,301:386-89.

Caspi A., Shiner L. (2006). Personality development. In: Damon W, Lerner R, Eisenberg N, editors. Handbook of Child Psychology: Social, Emotional, and Personality Development. 6th ed. New York: Wiley;300-365.

Ebstrup F., Eplov F., Pisinger C., Jørgensen T.(2011). Association between the Five Factor personality traits and perceived stress: Is the effect mediated by general self-efficacy? Anxiety Stress Coping,24:407-19.

Elfaoumy R. (2011). The relationship between personality traits and level of depression among depressed patients. Unpublished master thesis. Faculty of Nursing: Alexandria University.

Folkman S., Lazarus S. (1986). Stress processes and depressive symptomatology. Journal of Abnormal Psychology, 95:107-113.

Ghareeb M. (2000). An Arabic Version of Beck Depression Inventory. Available at: enwikipedia.org/wiki/Beck-Depression Inventory-43k. Retrieved on: January 2015. 
Gladstone L., Parker B., Malhi S., Wilhelm A. (2007). Feeling unsupported? An investigation of depressed patients' perceptions. Journal of Affective Disorder, 103(1-3):147-54.

Gomez R., Francis M. (2003). Generalized anxiety disorder: Relationships with Eysenck's, Gray's and Newman's theories. Personality and Individual Differences,34: 3-17.

Grabowska-Grzyb A., Jedrzejczak J., Naganska E. (2006). Risk factors for depression in patients with epilepsy. Epilepsy Behavior, 8: 411-417.

Griffith W., Zinbarg E., Craske G., Mineka S., Rose D., Waters M., Sutton M. (2010). Neuroticism as a common dimension in the internalizing disorders. Psychology Medicine,40(7):1125-1136.

John D.(2000). The Big Five Personality Inventory; http// www.outo.service.con/ bigfive/ ?score-bigfive. Retrieved on: April 2015.

Karimzade A., Besharat A.(2011). An investigation of the relationship between personality dimensions and stress coping styles. Procedia Social and Behavioral Sciences, 30:797 - 802.

Kotov R., Gamez W., Schmidt L., Watson D.(2010). Linking "Big” personality traits to anxiety, depressive, and substance use disorders: a meta-analysis. Psychology Bull,136:768-821.

Larry E. (2003). Beutler. Coping and Coping Styles in Personality and Treatment Planning: Introduction to the Special Series. Journal Of Clinical Psychology, 59(10):1045-1047.

Lucas E., Baird M. (2004). Extraversion and emotional reactivity. Journal of Personality and Social Psychology,86 (3): 473-485. 
Marnie M. (2008). Thesis of PhD in Psychology; The Role of Personality Following the September 11 th Terrorist Attacks: Big Five Trait Combinations and Interactions in Explaining Distress and Coping. California University.

Malone D.(2010). Thesis of MS in Psychology;. Individual Difference and Stress Reactions as Predictors of Performance in Pilot Trainees. Pennsylvania University; 225-227.

Malouff M., Thorsteinsson B., Schutte S.(2005). The relationship between the fivefactor model of personality and symptoms of clinical disorders: A meta-analysis. Journal of Psychopathology and Behavioral Assessment, 27:101-114.

Matheson K. Anisman H.(2003). Systems of coping associated with dysphoria, anxiety and depressive illness: a multivariate profile perspective Stress Journal, 6(3):223-234.

Moos R., Holahan C. (2003). Dispositional and contextual perspectives on coping: Toward an integrative framework. Journal of Clinical Psychology, 59(12):13871404.

Scher D., Ingram E., Segal V. (2005).Cognitive reactivity and vulnerability: empirical evaluation of construct activation and cognitive diatheses in unipolar depression. Journal of Clinical Psychology Review.,25(4):487-510.

Steel P., Schmidt J., Shultz J.(2008). Refining the relationship between personality and subjective well-being. Psychological Bulletin, 123:138-161.

Van Berkel H.(2009). The Relationship Between Personality, Coping Styles and Stress, Anxiety and Depression. Thesis of MS in Psychology; Canterbury University. 


\section{أساليب التكيف وسمات الشخصية لاى مرضى الآكتئاب}

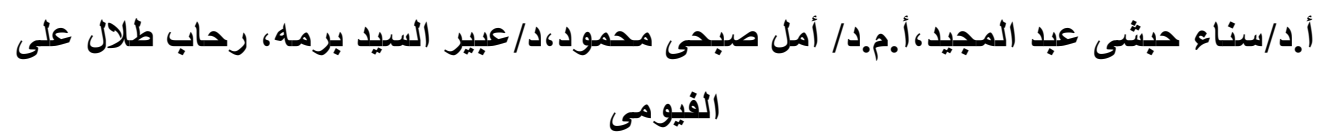

أستاذ التصريض النفسى والصحة العقليةـ كلبة التدريض- جامعة الآسكندرية، أستاذ مساعد التدريض التهم النفسى والصحة العقلية- كلية التمريض-جامعة بورسعيد - مدرس التمريض النفسى والصحة العقليةكلية التصريض-جامعة بورسعبد

\section{الـخـلاصــة}

خلفيـة المـوضـوع: الارتباط بين السمات الثخصية و انماط التكيف تساعدنا على معرفة الاشخاص الاكثر عرضة للاكتئاب و الثخصيات الغير منكيفة هم اكثر عرضة للضغوط النفسية ومن المحتمل استخدامهم نمط التكيف كالتجنب ـ هـف الـدراســة: معرفة العلاقة بين انماط التكيف و السمات الثخصية لدى الاشخاص المكتثئين. المـوضـوع والوسـائـل: صممت الدر اسة كمقارنة وصفية وشملت عينة البحث 150 مريض بمستشفي بورسعيد للصحة النفسية ببورسعيد ـ وقد نم جمع البيانات عن طريق استخدام ثلاث أدوات الاداة الاولى(مقياس انماط التكيف) لتقييم الافكار و الافعال التى يستخدمها الثخص للتكيف مع النفسية. الأداة الثانية (مقياس بيك للاكتئاب) مجمو عة من الاسئلة لقياس شدة وعمق وقوة و درجة الاكتئاب .الاداة الثالثة (مقياس السمات الثخصية) لتقييم السمات الثخصية. النتـائسـج:أوضحت النتائج وجود علاقة بين السمات الثخصية وانماط التكيف فى الاشخاص المكتئين.كما اسفرت النتائج عن وجود دلالة احصائية بين السمات الثخصية ودرجة الاكتئاب لدى الاشخاص غير المكتئبين ـ أيضا وجد ان الأثخاص الذين لايهم السمة العصابية يستخدمون الهروب كنمط تكيف لاى الاشخاص المكنثبين. كما أوضحت

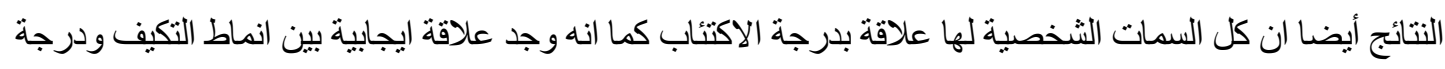
الاكتئاب. الـخـلاصــة: وجود ارتباط ذات دلالة احصائية بين أنماط التكيف و السمات الشخصية بين الاشخاص المكتئبين التوصيات:- عمل برنامج تعليمى يهدف الى تعليم الاشخاص المكتئبين وسائل جديدة للتكيف 